Ethiopian Journal of Environmental Studies \& Management 7(6): 664 - 669, 2014.

ISSN:1998-0507

doi: http://dx.doi.org/10.4314/ejesm.v7i6.9

Submitted: August 01, 2014

Accepted: October 08, 2014

\title{
EVALUATION OF A TREADLE PUMP FOR LOW LIFT IRRIGATION AT NCAM, ILORIN, NIGERIA
}

\author{
*MAKANJUOLA, M.B., MAKAR, T.A., OLLA, 0.0. AND KASALI, M.Y. \\ National Centre for Agricultural Mechanization, P.M.B 1525, Ilorin, Nigeria
}

\begin{abstract}
The treadle pump is a low speed foot operated single acting double cylinder piston pump for low lift irrigation. A scientific methodology is demonstrated for the evaluation of a metal treadle pump manufactured in Kenya to present pump performance data for the benefit of users. The experimental data indicated that the treadle pump cannot pull water from any source more than $7 \mathrm{~m}$ below the pump. Results showed an inverse relationship between discharge and delivery head with discharge varying from $1.3 \mathrm{l} / \mathrm{sec}$ to $0.8 \mathrm{l} / \mathrm{sec}$ for $1 \mathrm{~m}$ to $6 \mathrm{~m}$ delivery head respectively. The maximum overall efficiency of the treadle pump was found to be $89.7 \%$ at a static suction head of $2.5 \mathrm{~m}$. Treadle pumps are suitable, ergonomic and economical for supplying water for drinking and small-scale irrigation in developing countries.
\end{abstract}

Key Words: Discharge, Efficiency, Manual pump, Small-scale irrigation, Treadle

\section{Introduction}

Agricultural production in sub-Saharan Africa is adversely affected by erratic rainfall events within and between years. This has led to poor yields, low productivity, food insecurity and poverty. One of the major ways to increase agricultural production is to provide irrigation in areas hitherto not irrigated and grow crops not dependent on rainfall only. Traditional technologies using ropes and buckets or watering cans to lift and distribute from shallow wells and streams require low capital thus making such systems affordable. However, the low delivery capacity and labor-intensive nature make them highly unfavorable (Kamara et al., 2004). Improved water-lifting technologies, with relatively high efficiencies such as motorized pumps, on the other hand, are beyond the reach of many small-scale farmers, who usually irrigate relatively small plots of land and operate on a relatively small capital.

The lack of simple, affordable and welladapted water development technologies, suitable for the production conditions and needs of smallholder farmers in sub-Saharan Africa, in the recent past, was a serious handicap to efforts for achieving food security on the continent (Hyman et al., 1995; Brabben and Kay, 2000). Presently, a substantial variety of low-cost, affordable water management options exist. The use of the treadle pump for irrigation is widely acknowledged as one such option (EW, 2004). Treadle pumps are the most suitable and economical option to supply water for drinking and small-scale irrigation in developing countries. With the introduction of the treadle pump, mostly supported through the USAID and related development agencies, irrigation farming among smallscale farmers has grown in importance. The 
treadle pump can perform comparatively with a motorized pump, but costs considerably less.

The treadle pump is considered suitable and easily adaptable to African production conditions. There are two types of treadle pumps: those that lift water from a lower level to the height of the pump, commonly called suction pumps and those that lift water from a lower level to a height greater than the height of the pump, known as pressure pumps. The treadle pump is a low-lift, highcapacity, human-powered water lifting device designed to overcome common obstacles to irrigation by resource-poor farmers. It can lift 5-7 cubic meters of water per hour from wells and bore holes from a depth of $7 \mathrm{~m}$, as well as from surface water sources such as lakes and rivers (Adeoti et al., 2007). In Nigeria, where the surface irrigation is virtually the only system practicable by small scale farmers, the treadle pump is a viable option.

Performance evaluation is required to verify the truth of a manufacturer's claims for any developed product. It will also reveal if such a product can perform maximally in a site outside where it was developed. This will also make it possible to compare commercial products (Bralts et al. (1985). Thomas (1993) cited features of the treadle pump that determine good performance to include generously sized valves and passages, good seals and fast closing valves, correct gearing and smooth well lubricated linkages. In previous evaluation tests using existing FAO guidelines, Lambert and Faulkner (1991) reported that 0.24 ha was irrigable per operator per week using a treadle pump as compared to 0.03 ha irrigable using watering cans. Studies have also been made to compare the ergonomics of different manual irrigation pumps (Ali et al., 1987; BRRI, 1988).

The performance evaluation of a treadle pump is usually done by measuring discharge only. This study included measurement of the operating forces and efficiency of the pump. The main objective of the study was to determine the suitability of the pump for use in Nigerian agriculture. A focus on design defects and operational difficulties were made to proffer solutions to benefit both the manufacturers and the users of the pump.

\section{Methodology}

A unit of treadle pump, popularly known as super money maker, obtained from Kenya was assembled at the National Centre for Agricultural Mechanization (NCAM), Idofian, Kwara State, Nigeria for performance evaluation.

\section{Description and operating principles of the Treadle Pump}

Treadle pumps work on the principle of suction lift using a cylinder and piston to draw water from a resource below ground level such as a river or shallow groundwater. It was originally developed for hand pumping of domestic water and has been skillfully adapted for use in irrigation, where a much greater volume of water is needed, by changing the driving power from arms and hands to feet and legs. Two pistons are used, each connected to a treadle on which the operator stands and presses them up and down in a rhythmic motion.

The treadle pump comprises of three main parts: the pump head, the pipes and strainer, and the treadle and frame. The pump is primed at first use to eliminate trapped air in the suction pipe and cylinder. Water is sucked in through the strainer and rises up through the suction pipe to the dynamic ground water level from there it is lifted in a pulsating stream following the strokes of the two pistons. The action of the two cylinders provides a virtually continuous stream of water thus making the treadle pump more efficient than single cylinder pumps, where energy is needed to reaccelerate the water 
column after the longer pause in the changeover between strokes.

On the upward pumping stroke, the piston valve is closed. Water is sucked up through the pipe and into the cylinders. At the base of each cylinder is a foot-valve, called the check valve. The check valve is a simple rubber flap or disc made from an old truck or tractor tyre. As the water flows upwards, the check valve opens to allow passage into the cylinders. The water is drawn by the piston almost to the top of the cylinder. Simultaneously, water from the previous stroke is expelled from the cylinder to the field channel.

\section{System Performance}

Pump specification: The unit studied was a double cylinder with a height of $15.2 \mathrm{~cm}$, diameter of $12.1 \mathrm{~cm}$ and an effective height of $7.2 \mathrm{~cm}$. A suction pipe of $32 \mathrm{~mm}$ diameter and a delivery pipe of $25 \mathrm{~mm}$ diameter were utilized.

The system efficiency depends on various parameters such as the weight of the operator, strokes per minute, stroke length, head (water table) and discharge.

\section{Parameters for Estimation}

The following parameters were estimated:

Suction Head, $\mathrm{H}_{\mathrm{s}}(\mathrm{m})$ : is the maximum distance to the intake of a pump.

Delivery Head, $\mathrm{H}_{\mathrm{d}}(\mathrm{m})$ : is the vertical distance from the discharge outlet to the bottom of a water tank.

Total Head, $\mathrm{H}(\mathrm{m})$ : is expressed as:

$$
H=H_{s}+H_{d}
$$

Actual Volume (L): a calibrated container of known volume was filled and the volume recorded.

Displaced volume $\left(\mathrm{m}^{3}\right)$ :this is the volume of water lifted during each stroke of the pump expressed as:

volume $=\pi r^{2} h$

Actual Discharge $(\mathrm{L} / \mathrm{sec})$ : is the volume of water measured over a given number of strokes of pumping (cadence). Cadence is the frequency with which the treadle moves up and down. The cadence depends on the operator thus discharge varies from operator to operator.

Theoretical Discharge (L/sec): this is obtained from the volume of the cylinder per unit time, expressed as:

$$
\text { Discharge }=\frac{\pi r^{2} h}{s}
$$

System efficiency:

The efficiency for the treadle pump was estimated from the expression:

Efficiency $=\left(E_{\text {output }} / E_{\text {imput }}\right) \times 100$ where

$\mathrm{E}_{\text {input }}=$ mass of the operator $\mathrm{x}$ acceleration due to gravity $\mathrm{x}$ strokes/min $\mathrm{x}$ stroke length (joules/min)

$\mathrm{E}_{\text {output }}=$ discharge of water $\mathrm{x}$ acceleration due to gravity $\mathrm{x}$ total head (joules/min)

\section{Results and Discussion}

An inverse relationship was obtained for discharge rate and power requirement for various suction heads as shown in Table 1. Result showed that an increase in suction head resulted in an increase in power requirement as the discharge rate decreased. At low suction head, the pump was operated with ease and produced higher discharge using less power to operate.

The results also showed that for a given volume of water and water head, the time and cadence varied with the weight of the operator. It further indicated that higher discharges were achieved using operators with greater weights. At low heads, the operators' performances were close, but the difference became evident at higher heads. A further analysis of the results revealed that, 13 litres of water pumped at a total head of $2.5 \mathrm{~m}$ by a $90 \mathrm{~kg}$ weight operator resulted in a discharge of $1.18 \mathrm{l} / \mathrm{s}$ in $11 \mathrm{~s}$ at a cadence of 17 strokes. The $60 \mathrm{~kg}$ and $70 \mathrm{~kg}$ operators performed the same tasks with a discharge of $1.18 \mathrm{l} / \mathrm{s}$ with a cadence of 18 strokes in $12 \mathrm{~s}$. However, at a total head of $8.5 \mathrm{~m}$ the $90 \mathrm{~kg}$ 
operator had a discharge of $0.65 \mathrm{l} / \mathrm{s}$ in $18 \mathrm{~s}$ at a cadence of 19 strokes, whilst the $60 \mathrm{~kg}$ operator could only achieve a discharge of $0.43 \mathrm{l} / \mathrm{s}$ in $30 \mathrm{~s}$ at a cadence of 24 strokes. This disparity could be attributed to stress and fatigue setting in with the increased pressure required to lift to higher heads.

The results are indicative that the high output of the treadle pump could be attributed to the design features which included: the use of full body weight, leg muscles, the twin cylinder and alternating stroke which provided a continuous flow. In the operation of treadle pumps single-leg movement were taken as one stroke because each such stroke provided delivery. The speed of the operator determined the number of strokes per second which in turn determined the discharge. The force exerted by the operator to the pistons and the piston area determined the pressure achieved from the pump.

Operators possessing greater weights were also able to overcome the effort required at greater suction depths. Greater discharges were equally obtained when two operators pump thereby creating more energy needed for pumping.

In terms of gender consideration, men were the primary operators of the treadle pump with their weights ranging between 50 to $90 \mathrm{~kg}$. However, the performance of women and children was also evaluated. The women and children tested on the treadle pump were found not to generate enough energy required to overcome the initial force needed to prime the pump. Since pumping became easier after priming and water delivery was initiated, they were assisted by higher weight operators (preferably males) to initiate the pumping activity and subsequently they could operate with ease, though for shorter durations. The treadle pump was found to possess good ergonomics and most of the users opined that they did not feel any serious fatigue. Once the rhythmic pumping was attained, some operators could pump continuously for close to half an hour. Inference from the results indicated that pumping from a total head of $8.5 \mathrm{~m}$ and 2.5 $\mathrm{m}$ resulted in a pump capability of 2,340 and $4,320 \mathrm{l} / \mathrm{hr}$ respectively. Thus, pumping for two hour per day for the two different heads yielded 4,680 and 8640 1/day respectively. Satisfying a water requirement of 50,000 1/ha in this region, it is implied that the treadle pump would irrigate 0.2 and 0.1 ha respectively for $2.5 \mathrm{~m}$ and $8.5 \mathrm{~m}$ total head considered. Hence, the treadle pump technology can adequately meet the needs of most farmers since most of our farmlands are small sized plots ranging between $0.1-0.5$ ha.

\section{Conclusion}

The treadle pump is an improved and convenient manual pump capable of lifting water from a depth of $7 \mathrm{~m}$. The maximum efficiency of $89.7 \%$ was obtained at a suction head of $2.5 \mathrm{~m}$. Discharge obtained varied from $1.3 \mathrm{l} / \mathrm{s}$ to $0.8 \mathrm{l} / \mathrm{s}$ for delivery head of $1 \mathrm{~m}$ to $6 \mathrm{~m}$ respectively. The results of the study also revealed that an averaged sized operator pumped about 4,500 1/day at a total head of $8.5 \mathrm{~m}$ whilst about 9,000 1/day was attained at a head of $2.5 \mathrm{~m}$. This effectively irrigated a representative farm holding size of 0.2 ha predominant in this region. It was observed that though men are the main operators, women and children can equally operate the pump. The lack of fuel requirements and the ability to maintain and repair the pump using local materials and skill are attractive features for adoption of the treadle pump.

It is believed that a treadle pump unit made of wood would further endear its use due to a gain in tremendous reduction in weight thus aiding ease of transporting within our fragmented farmland.

The major source of losses recorded was that due to damaged valves. There is also a 
need to provide seals that are tight and can be easily replaced with minimal field down time.

\section{References}

Adeoti, A., Barry, B. Namara, R., Kamara, A. and Titiati, A. (2007). Treadle Pump Irrigation and Poverty in Ghana. Colombo, Sri Lanka: International Water Management Institute. (IWMI Research Report 117). 30p.

Ali, M., Taher Das, D.K., Nazrul Islam, S. M. and Msbah Uddin, A.K. (1987). Treadle Pump: Assessment of Engineering Aspects. Journal of Institute of Engineers, Bangladesh, 15: $23-30$.

Brabben, T. and Kay, M. (2000). Treadle Pumps - A Viable Option for Africa? GRID, Issue 16. IPTRID Network Magazine. International Program for Technology and Research in Irrigation and Drainage/Food and Agriculture Organization of the United Nations.

Bralts, V.F., Edwards, D.M. and Kesner, C.D. (1985). Field Evaluation of Drip/Trickle Irrigation Submain Units. In: Drip/Trickle Irrigation in Action. Proceedings of the Third International Drip/Trickle Irrigation Congress.

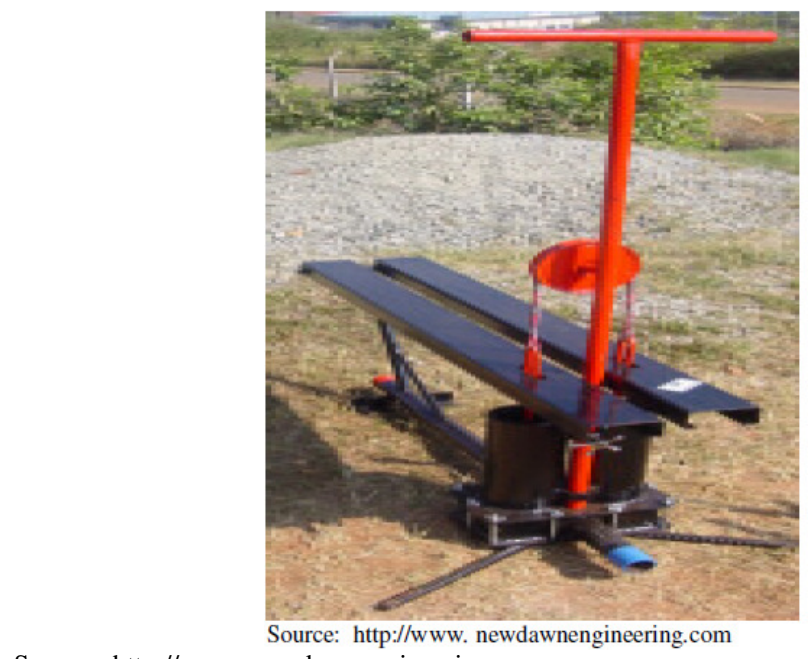

Center Plaza Holiday Inn, Fresno, California USA, pp $274-280$.

BRRI (1988). Annual Report on Determination and Identification of Ergonomic Characteristics of Manually Operated Pumps and Pumping Devices Widely Used By the Farmers. Agricultural Engineering Division.

EW (Enterprise Works). (2004). http://www.enterpriseworks.org/display $. c f m ? i d=2 \& s u b=1$

Hyman, E., Lawrence, E. and Singh, J. (1995).The ATI/USAID Market Gardeners Project in Senegal. Washington, D.C.: Appropriate Technology International (ATI).

Kamara, A., Danso, G., Mahu, S.A., Cofie, O. and Drechsel, P. (2004). Agricultural Water Investments and Poverty Impacts in West Africa: A Review of Treadle Pumps with a Focus on Ghana and Niger.

Lambert, R.A and Faulkner, R.D. (1991). The Efficient Use of Human Energy for Micro-Scale Irrigation. Agric. Engineering Research, 48: 171 - 183.

Thomas, T.H. (1993). The Performance Testing of Treadle Pumps. Development Technology Unit, Department of Engineering. Coventry: University of Warwick.

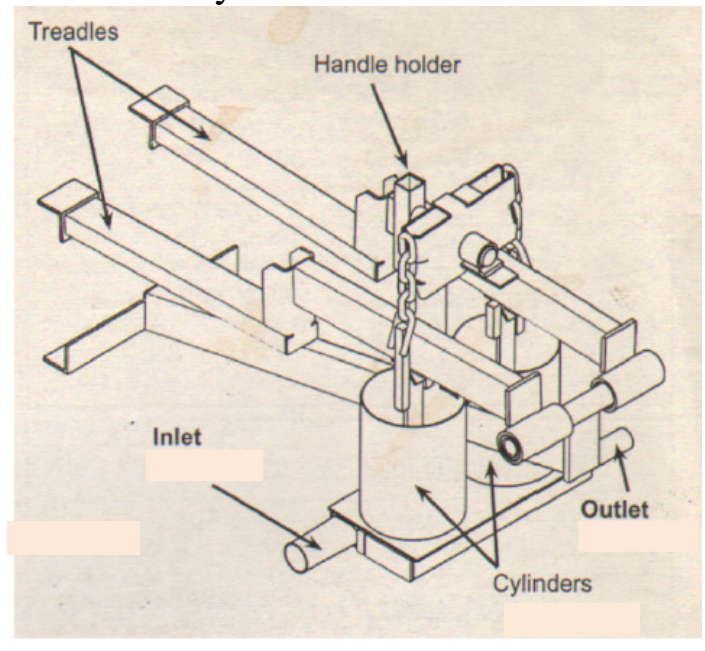

Source: http://www. newdawnengineering.com

Figure 1: A metal treadle pump: (a) pictorial view and (b) isometric projection. 


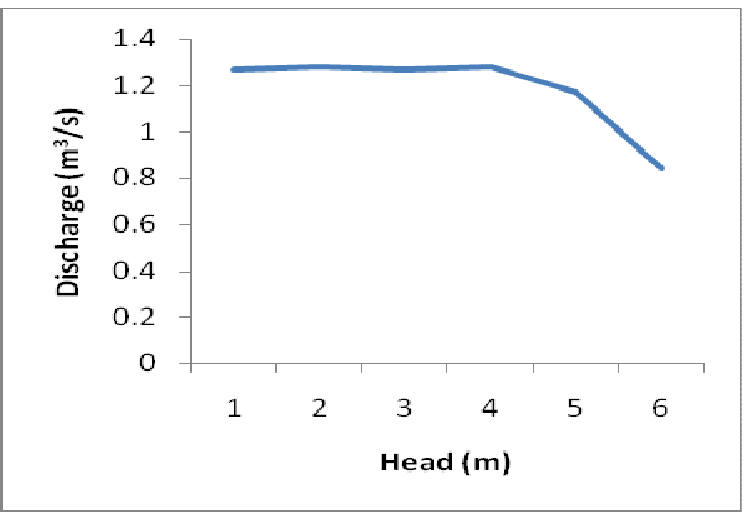

Figure 2: Graph of Discharge at different Heads for the treadle pump.

Table 1: Test data of treadle pump parameters.

\begin{tabular}{|c|c|c|c|c|c|c|c|c|c|c|}
\hline $\begin{array}{l}\text { Delivery } \\
\text { Head } \\
\text { (m) }\end{array}$ & $\begin{array}{l}\text { Suction } \\
\text { head }(\mathrm{m})\end{array}$ & $\begin{array}{l}\text { Total } \\
\text { Head } \\
\text { (m) }\end{array}$ & $\begin{array}{l}\text { Displaced } \\
\text { Volume (l) }\end{array}$ & $\begin{array}{l}\text { Measured } \\
\text { Volume (l) }\end{array}$ & $\begin{array}{l}\text { Time } \\
\text { (sec) }\end{array}$ & $\begin{array}{l}\text { Stroke } \\
\text { (No.) }\end{array}$ & $\begin{array}{l}\text { Theoretical } \\
\text { discharge Qt } \\
\text { l/sec }\end{array}$ & $\begin{array}{l}\text { Measured } \\
\text { discharge } \\
\text { Qa l/sec }\end{array}$ & $\begin{array}{l}\text { Efficiency } \\
\%\end{array}$ & $\begin{array}{l}\text { Brake } \\
\text { horse } \\
\text { power } \\
\text { (hp) }\end{array}$ \\
\hline 1 & 1.5 & 2.5 & 0.805 & 13 & 12 & 18 & 1.318 & 1.183 & 89.6 & 0.04 \\
\hline 1 & 1.7 & 2.7 & 0.805 & 13 & 11 & 18 & 1.317 & 1.182 & 89.7 & 0.047 \\
\hline 1 & 1.9 & 2.9 & 0.805 & 13 & 11.4 & 18 & 1.271 & 1.14 & 89.7 & 0.048 \\
\hline 1 & 2.1 & 3.1 & 0.805 & 13 & 11.6 & 18 & 1.249 & 1.12 & 90 & 0.051 \\
\hline 1 & 2.3 & 3.3 & 0.805 & 13 & 12.4 & 18 & 1.169 & 1.048 & 89.6 & 0.051 \\
\hline 1 & 2.5 & 3.5 & 0.805 & 13 & 10.8 & 18 & 1.342 & 1.204 & 89.7 & 0.062 \\
\hline 2 & 1.5 & 3.5 & 0.805 & 13 & 11 & 18 & 1.317 & 1.182 & 89.7 & 0.06 \\
\hline 2 & 1.7 & 3.7 & 0.805 & 13 & 11.2 & 18 & 1.294 & 1.161 & 89.7 & 0.063 \\
\hline 2 & 1.9 & 3.9 & 0.805 & 13 & 11.4 & 18 & 1.271 & 1.14 & 89.7 & 0.065 \\
\hline 2 & 2.1 & 4.1 & 0.805 & 13 & 11.6 & 18 & 1.249 & 1.121 & 90 & 0.067 \\
\hline 2 & 2.3 & 4.3 & 0.805 & 13 & 11.3 & 18 & 1.282 & 1.15 & 89.7 & 0.072 \\
\hline 2 & 2.5 & 4.5 & 0.805 & 13 & 11.6 & 19 & 1.319 & 1.121 & 85 & 0.074 \\
\hline 3 & 1.5 & 4.5 & 0.805 & 13 & 11.6 & 19 & 1.319 & 1.121 & 85 & 0.074 \\
\hline 3 & 1.7 & 4.7 & 0.805 & 13 & 11.4 & 18 & 1.272 & 1.14 & 89.4 & 0.078 \\
\hline 3 & 1.9 & 4.9 & 0.805 & 13 & 11.4 & 19 & 1.272 & 1.14 & 89.4 & 0.082 \\
\hline 3 & 2.1 & 5.1 & 0.805 & 13 & 11.4 & 19 & 1.272 & 1.14 & 89.4 & 0.085 \\
\hline 3 & 2.3 & 5.3 & 0.805 & 13 & 12 & 18 & 1.208 & 1.083 & 89.6 & 0.084 \\
\hline 3 & 2.5 & 5.5 & 0.805 & 13 & 12 & 19 & 1.275 & 1.083 & 84.9 & 0.092 \\
\hline 4 & 1.5 & 5.5 & 0.805 & 13 & 11.6 & 18 & 1.249 & 1.121 & 85 & 0.095 \\
\hline 4 & 1.7 & 5.7 & 0.805 & 13 & 11.4 & 18 & 1.272 & 1.14 & 89.4 & 0.096 \\
\hline 4 & 1.9 & 5.9 & 0.805 & 13 & 11.6 & 18 & 1.249 & 1.121 & 90 & 0.097 \\
\hline 4 & 2.1 & 6.1 & 0.805 & 13 & 11 & 19 & 1.39 & 1.182 & 79.2 & 0.12 \\
\hline 4 & 2.3 & 6.3 & 0.805 & 13 & 11.6 & 19 & 1.319 & 1.121 & 85 & 0.109 \\
\hline 4 & 2.5 & 6.5 & 0.805 & 13 & 11.8 & 18 & 1.23 & 1.102 & 87.2 & 0.108 \\
\hline 5 & 1.5 & 6.5 & 0.805 & 13 & 12.2 & 18 & 1.188 & 1.066 & 89.7 & 0.101 \\
\hline 5 & 1.7 & 6.7 & 0.805 & 13 & 11.8 & 18 & 1.228 & 1.102 & 89.7 & 0.108 \\
\hline 5 & 1.9 & 6.9 & 0.805 & 13 & 12.6 & 18 & 1.15 & 1.032 & 89.7 & 0.104 \\
\hline 5 & 2.1 & 7.1 & 0.805 & 13 & 12.4 & 18 & 1.169 & 1.048 & 89.6 & 0.109 \\
\hline 5 & 2.3 & 7.3 & 0.805 & 13 & 12.4 & 18 & 1.169 & 1.048 & 89.6 & 0.112 \\
\hline 5 & 2.5 & 7.5 & 0.805 & 13 & 12.6 & 18 & 1.15 & 1.032 & 89.7 & 0.113 \\
\hline 6 & 1.5 & 7.5 & 0.805 & 13 & 18.3 & 18 & 0.792 & 0.71 & 89.6 & 0.078 \\
\hline 6 & 1.7 & 7.7 & 0.805 & 13 & 18.8 & 18 & 0.771 & 0.691 & 89.6 & 0.078 \\
\hline 6 & 1.9 & 7.9 & 0.805 & 13 & 15.8 & 18 & 0.914 & 0.823 & 89.7 & 0.095 \\
\hline 6 & 2.1 & 8.1 & 0.805 & 13 & 16.4 & 18 & 0.884 & 0.739 & 89.7 & 0.094 \\
\hline 6 & 2.3 & 8.3 & 0.805 & 13 & 17.6 & 18 & 0.823 & 0.739 & 90 & 0.093 \\
\hline 6 & 2.5 & 8.5 & 0.805 & 13 & 18.2 & 19 & 0.84 & 0.714 & 85 & 0.094 \\
\hline
\end{tabular}

